\title{
High intensity interior aircraft noise increases the risk of high diastolic blood pressure in Indonesian Air Force pilots
}

\author{
Minarma Siagian, ${ }^{1}$ Bastaman Basuki, ${ }^{2}$ Dede Kusmana ${ }^{3}$ \\ ${ }^{1}$ Department of Physiology, Faculty of Medicine University of Indonesia, Jakarta, Indonesia \\ ${ }^{2}$ Department of Community Medicine, Faculty of Medicine University of Indonesia, Jakarta, Indonesia \\ ${ }^{3}$ Department of Cardiology, Faculty of Medicine University of Indonesia, Jakarta, Indonesia
}

\begin{abstract}
Abstrak
Tujuan Untuk menganalisis apakah bising pesawat terbang denyut nadi istirahat, dan faktor lain berperan meningkatkan risiko kejadian tekanan darah diastolik (TDD) pada penerbang TNI AU.

Metode Desain penelitian nested case-control. Data berasal dari rekam medis hasil pemeriksaan kesehatan berkala dan indoktrinasi latihan aerofisiologi di LAKESPRA Saryanto di Jakarta antara Januari 2003 - September 2008. Kelompok kasus ialah subjek dengan TDD $\geq 90 \mathrm{mmHg}$; kelompok kontrol adalah dengan TDD $\leq 89 \mathrm{mmHg}$. Setiap kasus dipadankan dengan 12 kontrol.

Hasil Di antara 567 penerbang, 544 (95,9\%) mempunyai rekam medis yang lengkap, dan diperoleh 40 kasus dan 480 kontrol. Penerbang yang biasa terpajan bising dalam pesawat 90-95 dB dibandingkan 70-80 dB mempunyai risiko 2,7 kali menderita TDD tinggi [rasio odds $(\mathrm{ORa})=2,70$; 95\% interval kepercayaan $(\mathrm{CI})=1,05-6,97]$. Penerbang dengan frekuensi nadi istirahat $\geq 81 /$ menit dibandingkan $\leq 80 /$ minute mempunyai risiko $2,7 \mathrm{kali} T D D$ tinggi $(\mathrm{ORa}=2,66 ; 95 \% \mathrm{CI}=1,26$ 5,61). Ditinjau dari segi total jam terbang, penerbang dengan total jam terbang 1401-11125 jam dibandingkan 147-1400 jam mempuyai risiko 3,2 kali menderita TDD tinggi (ORa =3,18; 95\% CI =1,01-10,03).
\end{abstract}

Kesimpulan Intensitas bising dalam pesawat yang tinggi, frekuensi nadi istirahat yang tinggi, jumlah jam terbang total yang tinggi meningkatkan risiko TDD tinggi. Pemeriksaan mawas diri frekuensi nadi istirahat oleh penerbang dapat dipakai untuk pengendalian TDD tinggi. (Med J Indones 2009; 18: 276-82)

\begin{abstract}
Aim To analyze the effects of aircraft noise, resting pulse rate, and other factors on the risk of high diastolic blood pressure (DBP) in Indonesian Air Force pilots.

Methods A nested case-control study was conducted using data extracted from annual medical check-ups indoctrination aerophysiologic training records at the Saryanto Aviation and Aerospace Health Institute (LAKESPRA) in Jakarta from January 2003 - September 2008. For analysis of DBP: the case group with DBP $\geq 90 \mathrm{mmHg}$ were compared with contral group with DBP $<79$ mmHG. One case matched to 12 controls.

Results Out of 567 pilots, 544 (95.9\%) had complete medical records. For this analysis there were 40 cases of high DBP and 480 controls for DBP. Pilots exposed to aircraft noise 90-95 dB rather than 70-80 dB had a 2.7-fold increase for high DBP [adjusted odds ratio $(\mathrm{ORa})=2.70 ; 95 \%$ confidence interval $(\mathrm{CI})=1.05-6.97$ ]. Pilots with resting pulse rates of $\geq 81 /$ minute rather than $\leq 80$ /minute had a 2.7 -fold increase for high $\mathrm{DBP}(\mathrm{ORa}=2.66 ; 95 \% \mathrm{CI}=1.26-5.61)$. In terms of total flight hours, pilots who had 1401-11125 hours rather than 147-1400 hours had a 3.2-fold increase for high DBP $(\mathrm{ORa}=3.18 ; 95 \% \mathrm{CI}=1.01-10.03)$.
\end{abstract}

Conclusion High interior aircraft noise, high total flight hours, and high resting pulse rate, increased risk for high DBP. Self assessment of resting pulse rate can be used to control the risk of high DBP. (Med J Indones 2009; 276: 276-82)

Key words: diastolic blood pressure, aircraft noise, resting pulse rate, military pilots

The relationship between noise and health has been suspected. ${ }^{1}$ Epidemiological and laboratory studies suggest that transient as well as chronic noise exposure have both temporary and permanent effects on human physiology. ${ }^{1,2}$ It has been linked with various physiological effects from general annoyance to sleep disturbances, cardiovascular effects, and noiseinduced hearing loss (NIHL). ${ }^{1,2}$ In Japan, aircraft noise exposure was found to be a factor in increasing the number of preschool children's physical and mental misbehaviors. ${ }^{3}$

Although a few have reported an increase in the prevalence of hypertension in people living around busy airports, the relationship has been sparsely investigated. ${ }^{4}$ HYENA study Hypertension and exposure to noise near airports, has been conducted 6000 persens living for for five years around one of six major European airport, and 
reported that significant exposure-response relationship was found between nightime aircraft noise exposure and risk of hypertension in people living around this busy airports. $^{5}$

Pilots are constantly exposed to aircraft noise, that can reach $90-120 \mathrm{~dB} \cdot{ }^{2,3}$ This chronic exposure is known to cause noise-induced hearing loss (NIHL). ${ }^{1}$ But nonauditory effects of noise need to be investigated. ${ }^{2}$ Short term and long-term exposures to aircraft noise will have auditory and non-auditory effects on the human body, with possible deleterious consequences on health, such as on the cardiovascular system.

It is therefore important to investigate the association between aircraft noise, on blood pressure, specifically diastolic blood pressure.

\section{METHODS}

A nested case-control study was carried out on pilots of the Indonesian Air Force (IAF) attending annual medical examinations and indoctrination and aerophysiologic training at the Saryanto Aviation and Space Medicine Institute from January 2003 to September 2008.

The medical examinations were carried out by trained doctors and nurses, specialist in their respective fields, according to strict and detailed procedures laid down by the Indonesian Air Force Medical Guidebook. ${ }^{6}$ The results of these examinations will end in recommendations of the eligibility of the pilots to continue flying or be grounded temporarily or permanently.

Cases were pilots with DBP $\geq 90 \mathrm{mmHg}$ and control with $\leq 89 \mathrm{mmHg} .^{7}$ The ratio of case to control was 1:12. Control was matched to case in terms of the month the case was diagnosed.

Data were extracted from records of annual medical examination and the indoctrination aerophysiologic training records.

The major risk factor for this study was interior aircraft noise. This noise was separated into 2 categories, $\leq 80$ $\mathrm{dB}$ (low) and $\geq 90 \mathrm{~dB}$ (high). Other potential aircraft risk factors were exterior aircraft noise, which was divided into 5 categories, $100 \mathrm{~dB}, 110 \mathrm{~dB}, 130 \mathrm{~dB}$, $140 \mathrm{~dB}$, and $160 \mathrm{~dB}$; type of aircraft, transport planes, fighter planes, and helicopters; and vibration, which was divided into low or high vibration. Aircraft noises and vibration measurements were obtained from the Air Force Health Office (Dinas Kesehatan Angkatan Udara) survey. ${ }^{8}$

The length of employment for cases was calculated from the year becoming an IAF pilot until diagnosed with high DBP. The length of employment for controls was calculated from the year becoming an IAF pilot up to the time the case was diagnosed with high DBP. For the purpose of analysis, the length of employment was divided into 2 categories: $2-10$ years and $11-25$ years.

Age diagnosed with high DBP was calculated from birth until the year diagnosed with hypertension. For the purpose of analysis, age was divided into 3 categories, 23-29 years, 30-39 years, and 40-48 years. Age on starting work was calculated from the birth year until the year becoming an IAF pilot. For analysis, age was divided into 2 groups, 19-22 years and 23-26 years

Rank was the most recent obtained by the pilots. For analysis, rank was divided into 2 groups, first officers (from second lieutenant to captain) and middle-ranked officers (major until colonel).

Total flight hours for cases were calculated from the year becoming a pilot until diagnosed with high DBP. For controls, total flight hours were calculated from the year becoming a pilot until diagnosed with high DBP. For analysis, total flight hours were divided into 2 categories, 147-1400 hours and 1401-11,125 hours. Annual average flight hours were calculated from total flight hours divided into 2 categories, 29-299 hours/year and 300-622 hours/year. Year of starting work was the year the subject became a pilot for, with 2 categories, the time periods 1980-1990 and 1991-2003.

Fasting blood glucose level was divided into 2 groups, less than or equal to $126 \mathrm{mg} / \mathrm{dL}$ and greater that $126 \mathrm{mg} / \mathrm{dL}$. Blood cholesterol level was divided into 2 groups, less than or equal to $200 \mathrm{mg} / \mathrm{dL}$ and more than $200 \mathrm{mg} / \mathrm{dL}$.

Body Mass Index (BMI) was calculated from body weight $(\mathrm{kg})$ divided by height $(\mathrm{m})$ squared or $\mathrm{kg} / \mathrm{m}^{2}$. BMI was divided into 3 groups, $18.00-22.99 \mathrm{~kg} / \mathrm{m}^{2}$, $23.00-24.99 \mathrm{~kg} / \mathrm{m}^{2}$, and $25.00-39.00 \mathrm{~kg} / \mathrm{m}^{2}{ }^{6}$. Waist circumference was in $\mathrm{cm}$ and was divided into 2 groups, normal $\leq 90 \mathrm{~cm}$ and high $>90 \mathrm{~cm}$.

Resting pulse rate was the number of pulses per minute taken after resting for 15 minutes, and divided into 2 groups, 50-80/minute and 81-101/minute. Selecting $80 /$ minute as the limit was based on the ROC curve. 
With $75.5 \%$ sensitivity and $61.4 \% 1$-specificity the value obtained was $79.5 /$ minute which was rounded out to $80 /$ minute.

Resting pulse pressure was the difference between systolic and diastolic blood pressures. It was divided into 2 groups, $10-40 \mathrm{mmHg}$ and $41-90 \mathrm{mmHg}$.

Statistical analyses were done using STATA 9.0 software. ${ }^{9}$ A number of risk factors were examined as to whether or not they were potential confounders and/or effect modifiers. Unconditional logistic regression analysis was used in order to determine the confounding effects and to determine the risk factors for hypertension. A risk factor was considered to be a potential confounder if in the univariate test it had a $P$-value $<0.25$ which would be considered as a candidate for the multivariate model along with all known risk factors for hypertension. ${ }^{10}$ Confounders were estimated by the method of maximum likelihood. Ninety-five percent confidence intervals were based on the standard error of coefficient estimates.
Odds ratios (OR) were estimated by the methods of maximum likelihood.

\section{RESULTS}

Out of 567 pilots, 544 (95.9\%) had complete medical data, $15.6 \%$ were normotensive, $75.6 \%$ with prehypertension, and $8.8 \%$ with stage 1 hypertension. From the prehypertension and hypertension group, 40 subjects had high diastolic pressure of $\geq 90 \mathrm{mmHg}$. With a ratio of 1:12, 480 subjects were chosen as control. The control was chosen during the month the case was diagnosed.

High diastolic blood pressure (DBP) had occurred during the first two years of employment (Table 1). From Table 1 it can also be seen that the highest occurrence of high DBP was found in subjects with 11-25 years of employment, annual average flight hours of 29-299 hours/year, total flight hours of 1401-11,125 hours, and year of starting work between 1991-2003.

Table 1. Some demographic, work characteristics and the risk of high DBP

\begin{tabular}{|c|c|c|c|c|c|c|c|}
\hline & \multicolumn{4}{|c|}{ Diastolic pressure } & \multirow{3}{*}{$\begin{array}{l}\text { Crude odds } \\
\text { ratio }\end{array}$} & \multirow{3}{*}{$\begin{array}{c}95 \% \\
\text { Confidence Interval }\end{array}$} & \multirow{3}{*}{$p$} \\
\hline & \multicolumn{2}{|c|}{$\begin{array}{l}\text { Not high } \\
(\mathrm{n}=480)\end{array}$} & \multicolumn{2}{|c|}{$\begin{array}{l}\text { High } \\
(\mathrm{n}=40)\end{array}$} & & & \\
\hline & $\mathrm{n}$ & $\%$ & $\mathrm{n}$ & $\%$ & & & \\
\hline \multicolumn{8}{|l|}{ Length of employment } \\
\hline $2-10$ years & 255 & 53.1 & 15 & 37.5 & 1.00 & Reference & \\
\hline $11-25$ years & 225 & 46.9 & 25 & 62.5 & 1.89 & $0.97-3.67$ & 0.061 \\
\hline \multicolumn{8}{|l|}{ Annual average flight hours } \\
\hline 29-299 hours per year & 437 & 91.0 & 35 & 87.5 & 1.00 & Reference & \\
\hline $300-622$ hours per year & 43 & 9.0 & 5 & 12.5 & 1.45 & $0.54-3.90$ & 0.460 \\
\hline \multicolumn{8}{|l|}{ Age diagnosed } \\
\hline 23-29 years & 168 & 35.0 & 9 & 22.5 & 1.00 & Reference & \\
\hline $30-39$ years & 253 & 52.7 & 22 & 55.0 & 1.62 & $0.73-3.61$ & 0.235 \\
\hline $40-48$ years & 59 & 12.3 & 9 & 22.5 & 2.85 & $1.08-7.51$ & 0.035 \\
\hline \multicolumn{8}{|l|}{ Age on starting work } \\
\hline 19-22 years & 313 & 65.2 & 20 & 50.0 & 1.00 & Reference & \\
\hline 23-26 years & 167 & 34.8 & 20 & 50.0 & 1.87 & $0.98-3.58$ & 0.057 \\
\hline \multicolumn{8}{|l|}{ Rank } \\
\hline First officer & 285 & 59.4 & 19 & 47.5 & 1.00 & Reference & \\
\hline Middle-ranked officer & 195 & 40.6 & 21 & 52.5 & 1.65 & $0.85-3.08$ & 0.146 \\
\hline \multicolumn{8}{|l|}{ Total flight hours } \\
\hline 147-1400 hours & 228 & 47.5 & 11 & 27.5 & 1.00 & Reference & \\
\hline 1401-1.1125 hours & 252 & 52.5 & 29 & 72.5 & 2.39 & $1.16-4.88$ & 0.017 \\
\hline \multicolumn{8}{|l|}{ Year of starting work } \\
\hline $1980-1990$ & 110 & 22.9 & 15 & 37.5 & 1.00 & Reference & \\
\hline $1991-2003$ & 370 & 77.1 & 25 & 62.5 & 0.05 & $0.25-0.97$ & 0.041 \\
\hline
\end{tabular}


Subjects with normal DBP and high DBP were equally distributed in terms of annual average flight hours. When compared to the reference, subject diagnosed at the age of 40-48 years, middle-ranked officers, length of employment 11-25 years, total flight hours 140111,125 hours, age starting work $23-26$ years tend to be at risk for high DBP.

Table 2 shows that from 520 subjects, 142 pilots $(27.3 \%)$ were overweight and $286(55.0 \%)$ were obese. Blood cholesterol levels were comparable in both groups. High cholesterol levels occurred in both normal (50.4\%) and high DBP (52.5\%) group.

Table 2 shows that subjects with normal DBP and high DBP were similarly distributed in terms of fasting blood glucose levels, blood cholesterol levels, body mass index (BMI), and waist circumference. Subject with high resting pulse rate or high pulse pressure had a higher risk of high DBP compared to the reference group.
In Table 3, subject with normal and high DBP were similarly distributed in terms of type of aircraft and exterior aircraft noise. Compared to the reference, intense interior aircraft noise of $90-95 \mathrm{~dB}$ and aircraft vibration tend to be a risk for high DBP.

Table 4 reveals three dominant factors which increased the risk of high DBP. These factors were high intensity interior aircraft noise [adjusted odds ratio $(\mathrm{ORa}=$ 2.70)], high total flight hours $(\mathrm{ORa}=3.18)$, and high resting pulse rate $(\mathrm{ORa}=2.66)$. Compared to interior aircraft noise of 70-80 dB, an interior aircraft noise of 90-95 dB increased the risk of high DBP by 2.7 fold [risiko odds suaian $(\mathrm{ORa})=2.70$ ]. High total flight hours (1401-11,125 hours) increased the risk of high $\mathrm{DBP}$ by 3 fold $(\mathrm{ORa}=3.18)$. High resting pulse rate (81-101 per minute) increased the risk of high DBP by 2.5 fold $(\mathrm{ORa}=2.66)$.

Table 2. Some laboratory, physiological findings and the risk of high DBP

\begin{tabular}{|c|c|c|c|c|c|c|c|}
\hline & \multicolumn{4}{|c|}{ Diastolic pressure } & \multirow{3}{*}{$\begin{array}{l}\text { Crude } \\
\text { odds } \\
\text { ratio }\end{array}$} & \multirow{3}{*}{$\begin{array}{c}95 \% \\
\text { Confidence } \\
\text { Interval }\end{array}$} & \multirow{3}{*}{$p$} \\
\hline & \multicolumn{2}{|c|}{$\begin{array}{l}\text { Not high } \\
(\mathrm{n}=480)\end{array}$} & \multicolumn{2}{|c|}{$\begin{array}{l}\text { High } \\
(\mathrm{n}=40)\end{array}$} & & & \\
\hline & $\mathrm{n}$ & $\%$ & $\mathrm{n}$ & $\%$ & & & \\
\hline \multicolumn{8}{|c|}{ Fasting blood glucose level } \\
\hline Normal & 476 & 99.2 & 39 & 97.5 & 1.00 & Reference & \\
\hline High & 4 & 0.8 & 1 & 2.5 & 3.05 & $0.33-27.97$ & 0.324 \\
\hline \multicolumn{8}{|c|}{ Blood cholesterol level } \\
\hline Normal & 238 & 49.6 & 19 & 47.5 & 1.00 & Reference & \\
\hline High & 242 & 50.4 & 21 & 52.5 & 1.09 & $0.57-2.07$ & 0.800 \\
\hline \multicolumn{8}{|c|}{ Body mass index } \\
\hline Normal & 78 & 16.2 & 4 & 10.0 & 1.00 & Reference & \\
\hline Overweight & 140 & 29.2 & 12 & 30.0 & 1.67 & $0.52-5.36$ & 0.387 \\
\hline Obese & 262 & 54.6 & 24 & 60.0 & 1.79 & $0.60-5.30$ & 0.296 \\
\hline \multicolumn{8}{|c|}{ Waist circumference } \\
\hline Normal & 443 & 92.3 & 35 & 87.5 & 1.00 & Reference & \\
\hline High & 37 & 7.7 & 5 & 12.5 & 1.71 & $0.63-4.63$ & 0.291 \\
\hline \multicolumn{8}{|c|}{ Resting pulse rate } \\
\hline Normal & 351 & 73.1 & 20 & 50.0 & 1.00 & Reference & \\
\hline High & 129 & 26.9 & 20 & 50.0 & 2.72 & $1.42-5.22$ & 0.003 \\
\hline \multicolumn{8}{|c|}{ Resting pulse pressure } \\
\hline Normal & 389 & 81.0 & 30 & 75.0 & 1.00 & Reference & \\
\hline High & 91 & 19.0 & 10 & 25.0 & 1.42 & $0.67-3.02$ & 0.356 \\
\hline
\end{tabular}


Tabel 3. Some aircraft characteristics and the risk of high DBP

\begin{tabular}{|c|c|c|c|c|c|c|c|}
\hline & \multicolumn{4}{|c|}{ Diastolic pressure } & \multirow{3}{*}{ Crude odds ratio } & \multirow{3}{*}{$\begin{array}{c}95 \% \\
\text { Confidence } \\
\text { Interval }\end{array}$} & \multirow{3}{*}{$p$} \\
\hline & \multicolumn{2}{|c|}{$\begin{array}{l}\text { Not high } \\
(\mathrm{n}=480)\end{array}$} & \multicolumn{2}{|c|}{$\begin{array}{l}\text { High } \\
(\mathrm{n}=40)\end{array}$} & & & \\
\hline & $\mathrm{n}$ & $\%$ & $\mathrm{n}$ & $\%$ & & & \\
\hline \multicolumn{8}{|c|}{ Type of aircraft } \\
\hline Transport & 207 & 43.1 & 17 & 42.5 & 1.00 & Reference & \\
\hline Fighter & 161 & 33.6 & 11 & 27.5 & 0.83 & $0.38-1.83$ & 0.646 \\
\hline Helicopter & 112 & 23.3 & 12 & 30.0 & 1.30 & $0.60-2.83$ & 0.501 \\
\hline \multicolumn{8}{|c|}{ Exterior aircraft noise } \\
\hline $100 \mathrm{~dB}$ & 66 & 13.7 & 5 & 12.5 & 1.00 & Reference & \\
\hline $110 \mathrm{~dB}$ & 184 & 38.3 & 16 & 40.0 & 1.15 & $0.40-3.26$ & 0.796 \\
\hline $130 \mathrm{~dB}$ & 78 & 16.3 & 8 & 20.0 & 1.35 & $0.42-4.34$ & 0.610 \\
\hline $140 \mathrm{~dB}$ & 119 & 24.8 & 8 & 20.0 & 0.89 & $0.28-2.82$ & 0.840 \\
\hline $160 \mathrm{~dB}$ & 33 & 6.9 & 3 & 7.5 & 1.20 & $0.27-5.33$ & 0.811 \\
\hline \multicolumn{8}{|c|}{ Interior aircraft noise } \\
\hline $70-80 \mathrm{~dB}$ & 363 & 75.6 & 24 & 60.0 & 1.00 & Reference & \\
\hline $90-95 \mathrm{~dB}$ & 117 & 24.4 & 16 & 40.0 & 2.07 & $1.06-4.03$ & 0.032 \\
\hline \multicolumn{8}{|c|}{ Aircraft vibration } \\
\hline Low & 404 & 84.2 & 30 & 75.0 & 1.00 & Reference & \\
\hline High & 76 & 15.8 & 10 & 25.0 & 1.33 & $0.91-1.94$ & 0.138 \\
\hline
\end{tabular}

Tabel 4. The relationship between interior aircraft noise, total flight hours, and resting pulse rate and the risk of high DBP

\begin{tabular}{|c|c|c|c|c|c|c|c|}
\hline & \multicolumn{4}{|c|}{ Diastolic pressure } & \multirow{3}{*}{$\begin{array}{c}\text { Adjusted } \\
\text { odds ratio* }\end{array}$} & \multirow{3}{*}{$\begin{array}{c}95 \% \\
\text { Confidence } \\
\text { Interval }\end{array}$} & \multirow{3}{*}{$p$} \\
\hline & \multicolumn{2}{|c|}{$\begin{array}{l}\text { Not high } \\
(n=480)\end{array}$} & \multicolumn{2}{|c|}{$\begin{array}{c}\text { High } \\
(\mathrm{n}=40)\end{array}$} & & & \\
\hline & $\mathrm{n}$ & $\%$ & $\mathrm{n}$ & $\%$ & & & \\
\hline \multicolumn{8}{|l|}{ Interior aircraft noise } \\
\hline $70-80 \mathrm{~dB}$ & 363 & 75.6 & 24 & 60.0 & 1.00 & Reference & \\
\hline $90-95 \mathrm{~dB}$ & 117 & 24.4 & 16 & 40.0 & 2.70 & $1.05-6.97$ & 0.040 \\
\hline \multicolumn{8}{|l|}{ Resting pulse rate } \\
\hline Normal & 351 & 73.1 & 20 & 50.0 & 1.00 & Reference & \\
\hline High & 129 & 26.9 & 20 & 50.0 & 2.66 & $1.26-5.61$ & 0.010 \\
\hline \multicolumn{8}{|l|}{ Total flight hours } \\
\hline $147-1400$ hours & 228 & 47.5 & 11 & 27.5 & 1.00 & Reference & \\
\hline $1401-11,125$ hours & 252 & 52.5 & 29 & 72.5 & 3.18 & $1.01-10.03$ & 0.049 \\
\hline
\end{tabular}




\section{DISCUSSION}

A limitation of the study was that the source of the data was records of medical examinations and indoctrination and aerophysiological training forms from 20032008. However the examinations followed the rigid instructions of the standardized Technical Guidelines for Medical Tests and Examinations of the IAF. Another limitation was that work-related stress, exercise, and smoking were not analyzed in this study.

Data from the Framingham study showed that DBP increase progressively until age 50-55 years, levels for several years afterwards, to finally decrease with age. ${ }^{13}$ In this study, factors associated with age, such as longer duration of employment, older age when diagnosed, older age on entering employment, and higher rank, were found to be risks for high DBP.

Total flight hours of equal to or more than 1401 hours was a risk for high $\mathrm{DBP}(\mathrm{P}=0.017)$. The total flight hours is related to the duration of exposure to noise, therefore, the longer the duration of exposure to noise, the greater the effect. The relationship is dose-dependent.

Pilots starting work in 1991-2003 had a 5\% smaller risk of high $\mathrm{DBP}(\mathrm{P}=0.041)$. This is because these pilots are younger than those starting work in 1980-1990.

High resting pulse rate was found to be a risk factor for high $\mathrm{DBP}(\mathrm{P}=0.003)$. According to the Framingham study, increased diastolic pressure is the result of increased peripheral resistance. ${ }^{11}$ Increased peripheral resistance is mainly caused by high sympathetic tone. High resting pulse rate is related to increased sympathetic tone, therefore pulse rate reflects sympathetic tone.

Intense interior aircraft noise of $90-95 \mathrm{~dB}$ increased the risk of high DBP $(\mathrm{P}=0.032)$. Previous studies, in Indonesia and Italy, showed that aircraft noise is associated with increased DBP. ${ }^{12-14}$ An experimental study in Indonesia on 14 flight instructors and cadets of the Flight Academy in Curug (PPLP Curug) demonstrated that exposure to aircraft noise of 90-105 $\mathrm{dB}$ for 30 minutes significantly increased DBP without significant increase in systolic blood pressure. ${ }^{12}$ Another study was a cross-sectional study to identify the effects of chronic exposure to aircraft noise as a cardiovascular risk factor in Italian military pilots. The subjects were 416 pilots and 150 control within the same age group. The pilots were divided into 2 groups, those exposed to noise from turboprop aircrafts $(93 \mathrm{~dB})$ and those exposed to jet planes $(79 \mathrm{~dB})$. Results showed an increase in the prevalence of hypertension, which was almost always diastolic in pilots of turboprops $(\mathrm{P}<0.005)$ and jets $(\mathrm{P}<0.001)$ compared to control. ${ }^{13}$ This also showed a dose-dependant relationship.

High aircraft vibration was found to be a risk factor for high DBP $(\mathrm{P}=0.138)$. The effect of whole body vibration in increasing DBP has not been widely studied. The effect is probably via increased sympathetic activity causing increased peripheral resistance. ${ }^{11}$

In the final model, the risk factors for high DBP were high noise intensity $(\mathrm{P}=0.040)$, high total flight hours $(\mathrm{P}=0.049)$, and high resting pulse rate $(\mathrm{P}=0.010)$. Intense aircraft noise and increased total flight hours reflect a greater impact of noise on the cardiovascular system as was shown by the study in Italy. ${ }^{13,14}$

In conclusion, high interior aircraft noise, high total flight hours, as well as high resting pulse rate increased risk for high DBP. Self assessment of resting pulse rate can be used to control the risk of high DBP.

\section{Acknowledgments}

The authors wish to thank all subjects who willingly participated in this study. The authors would also like to express their sincerest gratitude for the director of Lakespra, Air Commodore Dr Mariono Reksoprodjo, SpOG, the former Surgeon General of the Indonesian Air Force, Air Commodore (ret.) dr Julizir Muzahar, SpA, and the former Surgeon General of the Armed Forces, Vice Air Marshal (ret.) Dr Achmad Hidayat, $\mathrm{SpB}$ for making this study possible.

The authors would also like to convey their heartfelt appreciation to Dr. Elisabeth Emerson who kindly took the time to read and give suggestions to improve the manuscript.

Parts of this study have been presented in the $5^{\text {th }}$ Malaysia Indonesia Brunei Medical Sciences Conference 2009 in Jakarta.

\section{REFERENCES}

1. World Health Organization. Guidelines for community noise. Geneva: The Organization; 2000.

2. Babisch W. The noise/stress concept, risk assessment and research needs. Noise \& Health. 2002;4(16):1-11.

3. Matsui T, Miyakita T. Association between blood pressure and aircraft noise exposure around Kadena airfields in 
Okinawa. The 2001 International Congress and Exhibition on Noise Control Engineering. The Hague: The Netherlands; 2001.

4. Rosenlund M, Berglund N, Pershagen G, Järup L, Bluhm G. Increased prevalence of hypertension in a population exposed to aircraft noise. Occup Environ Med. 2001;58:769-73.

5. Järup L, Dudley M-L, Babisch W, Houthuijs D, Swart W, Pershagen G, et al. Hypertension and exposure to noise near airports (HYENA): study design and noise exposure assessment. Environ Health Perspect. 2005;113:1473-8.

6. Tentara Nasional Indonesia; Markas Besar Angkatan Udara. Buku petunjuk teknis TNI AU tentang uji dan pemeriksaan kesehatan. Jakarta: TNI AU; 2007.

7. Joint National Committee on Prevention Detection, Evaluation, and Treatment of High Blood Pressure. The seventh report of the Joint National Committee on prevention detection, evaluation, and treatment of high blood pressure. JAMA. 2003;289:2560-72.
8. Dinas Kesehatan TNI AU (RI). Hasil survey kebisingan dan vibrasi oleh Diskesau. Jakarta: Lakespra. 2005.

9. Stata Corp. Stata Statistical Software: Release 9.0. Getting started with Stata for Windows. Texas: Stata Corporation; 2007.

10. Hosmer DW, Lemeshow S. Applied logistic regression. $2^{\text {nd }}$ edition. New York: John Wiley \& Sons; 2000.

11. Oparil S, Weber M. Hypertension: companion to Brenner \& Rector's the kidney. $2^{\text {nd }}$ ed. Philadelphia: Elsevier Saunders; 2005.

12. Setiadji VS, Tanzil A, Siagian M, Wirosoekarto S, Dana M. Pengaruh bising pesawat udara terhadap beberapa parameter ilmu faal awak pesawat. [unpublished] 1980.

13. Tomei F, Papaleo B, Baccolo TP, Tomao E, Alfi P, Fantini $\mathrm{S}$. Chronic noise exposure and the cardiovascular system in aircraft pilots [article in Italian]. Med Lav. 1996;87:394-410.

14. Tomei F, De Sio S, Tomao E, Anzelmo V, Baccolo TP, Ciarocca $\mathrm{M}$, et al. Occupational exposure to noise and hypertension in pilots. Int J Environ Health Res. 2005;15:99-106. 